\title{
Reflecting on the Right to Development from the Perspective of Global Environmental Change and the 2030 Agenda for Sustainable Development
}

\author{
Imme Scholz
}

\begin{abstract}
Contents

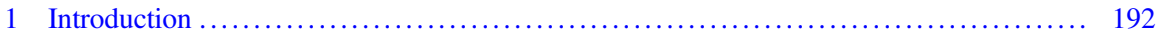

2 Global Environmental Change and Human Development ......................... 195

3 What Follows from This for the Right to Development? Human Development Within the Limits of the Earth's Ecosystems ..................................... 199

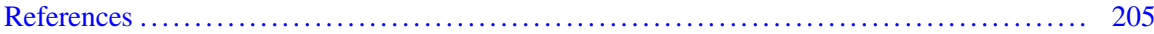

\begin{abstract}
The conceptual and legal relationship between human rights, human development and environmental protection is not a straightforward one. The 2030 Agenda for Sustainable Development and the Paris Climate Agreement adopted in 2015 link improvements in human development to human rights and to mitigating global changes in climate and the environment. The UN Declaration on the Right to Development (UNDRTD) adopted in 1986, however, does not include any explicit obligation to protect the natural environment, and to contribute to the provision of global environmental goods. The article explains how global environmental change is defined, how it is linked with human development and how it manifests itself. Then, the article takes a closer look at the UNDRTD and how it could be linked with global environmental change. Finally, the article proposes two concepts that could help to situate the UNDRTD within the challenges of the twenty-first century as exemplified in the 2030 Agenda. First, humanity should be introduced as a third category of right-holders (in addition to individuals and groups). This would include future generations more explicitly than now and put the relationships between species or life-forms as interdependent parts of the web of life into focus. Second, therefore, the rights of life forms should be established to transcend the conceptual boundaries of human rights and develop norms that govern the interdependencies between humans as well as plants and animals in the broadest sense.
\end{abstract}

\footnotetext{
I. Scholz (ه)

German Development Institute/Deutsches Institut für Entwicklungspolitik (DIE), Bonn,

Germany

e-mail: imme.scholz@die-gdi.de
} 


\section{Introduction}

The UN Declaration on the Right to Development (UNDRTD) adopted in 1986 and the 2030 Agenda for Sustainable Development adopted in 2015 share a universal concept of development that refers both to individual and collective dimensions of prosperity and thus includes the rights of future generations. ${ }^{1}$ They thus offer a definition of the relationship between development and human rights that is very relevant for the twenty-first century. The core norm of the UNDRTD has been defined later as "the right of peoples and individuals to the constant improvement of their wellbeing and to a national and global enabling environment conducive to just, equitable, participatory and human-centred development respectful of all human rights". 2 Development thus refers to a people-centred and participatory process that aspires to achieve all human rights, it encompasses both individual and collective rights, and it binds states to promote human wellbeing within the borders of their own territory as well as beyond them. ${ }^{3}$ It compels states to engage in international cooperation in order to remove obstacles for development and the achievement of human rights.

This is not only relevant for a world characterized by economic globalization and increasing interdependencies but also in times where the rationale for international cooperation has to be defended against nationalist trends in many countries on all continents. In particular, the consensus among Western countries, within the European Union and the G7, that rule-based international cooperation is beneficial for their prosperity and their objectives in international relations, seems to be crumbling, under the pressures of nationalist framings of increasing domestic economic inequalities and the rise of competing nations, notably China.

The linkage made to the first and second generations of human rights by the UNDRTD is echoed by the preamble to the Paris Agreement on Climate Change under the UNFCCC, which was adopted in 2015. It is the first time that a multilateral environmental agreement makes such a reference. The preamble acknowledges "that climate change is a common concern of humankind" and that "Parties should, when taking action to address climate change, respect, promote and consider their respective obligations on human rights". The Paris Agreement also includes "provisions to promote gender equality, and participation, sustainable development, and poverty eradication as side-benefits, or, more generally, as a context for climate action. Thus,

\footnotetext{
${ }^{1}$ UNDRTD Article 1 states in its first paragraph: "The right to development is an inalienable human right by virtue of which every human person and all peoples are entitled to participate in, contribute to, and enjoy economic, social, cultural and political development, in which all human rights and fundamental freedoms can be fully realized."

${ }^{2}$ This definition was elaborated in a broad consultative process by the High-Level Task Force on the Right to Development established in 2010 by the Human Rights Council, and which can be considered to being authoritative (quoted after Vandenbogaerde 2013, p. 19).

${ }^{3}$ de Feyter (2013) and Fukuda-Parr (2016).
} 
the Paris Agreement contributes to the development of a political narrative justifying climate action by reference to human rights".

The 2030 Agenda for Sustainable Development, the other landmark agreement of the UN in 2015, links human development rather closely with environmental protection. The preamble specifies that the states that adopted the Agenda "are determined to end poverty and hunger, in all their forms and dimensions, and to ensure that all human beings can fulfill their potential in dignity and equality and in a healthy environment". The negotiation of the 2030 Agenda was rooted in two distinct policy communities and processes: the development community was engaged in defining new objectives for poverty reduction and social development, building on the Millennium Development Goals that expired in 2015. The environmental community (together with a smaller part of the development community) focused on elaborating the Sustainable Development Goals ${ }^{5}$ that had been agreed during the UN Conference on Sustainable Development 2012 in Rio de Janeiro. Both processes converged in the Agenda whose elaboration had thus been informed both by the principles of the Rio Declaration 1992 and by 'other instruments such as the Declaration on the Right to Development' and recognizes the need to build societies 'that are based on respect for human rights (including the right to development) ${ }^{6} .{ }^{6}$ Like the UNDRTD, the Agenda emphasizes participation and the need for international cooperation in order to implement its set of 17 Sustainable Development Goals. ${ }^{7}$ However, "the SDGs themselves and the attached targets do not represent a firm rights orientation". ${ }^{8}$

Both agreements adopted in 2015, if implemented, aim at improving human development inter alia by protecting it against threats associated with global changes in climate and the environment. In other words, they have the potential to redefine the relationship between human and economic development on the one hand, and the natural environment on the other. The 2030 Agenda specifies 17 goals to improve human development and to protect the planet's ecosystems. The Paris Agreement sets out to keep average global warming below $1.5^{\circ} \mathrm{C}$ and to achieve global zero net emissions by the middle of the century.

It is difficult to link these concerns directly with the UNDRTD as the latter does not include any explicit mention of the natural environment. The second paragraph of Article 1 (see footnote 1) mentions the "full sovereignty" of peoples over their

\footnotetext{
${ }^{4}$ Mayer (2016), pp. 109-110.

${ }^{5}$ The SDGs were proposed by Colombia and Guatemala in the preparation of the Rio Conference 2012 in order to strengthen international consensus on cooperation for solving pressing and new global environmental problems, and for linking them systematically with improvements in human development. They explicitly referred to the success of the Millennium Development Goals in building support and guiding development assistance expenditure towards them, Scholz (2017).

${ }^{6}$ Arts and Tamo (2016), p. 222.

${ }^{7}$ Arts and Tamo (2016), p. 228.

${ }^{8}$ Arts and Tamo (2016), p. 247.
} 
"natural wealth and resources", 9 and the definition of the core norm of 2010 mentioned above includes the term "enabling environment". It is debatable, however, whether these terms explicitly include the obligation to protect the natural environment, and to contribute to the provision of global environmental goods. In the 1990s and early 2000s, developing countries often rather considered these concerns as an "obstacle to development" as they subjected the economic use of natural wealth and resources to environmental provisions and thus made it more costly. In this line of argumentation, these provisions and costs were juxtaposed to poverty reduction. Both agreements adopted in 2015 reflect the insight that their implementation requires fundamental changes in development pathways and in patterns of production and consumption in order to accommodate environmental and social concerns. Therefore, the agreements are both universal and equally valid for rich and poor countries, and do not describe development as a process of catching up with current prosperity patterns of the "North". The UNDRTD is universal, too, but is not as explicit with regard to the relevance of environmental objectives for human development as the previous two.

Do the Paris Agreement and the 2030 Agenda require a reinterpretation or even a reformulation of the Declaration on the Right to Development? The objective of this article is to explain how the far-reaching impacts of global climate and environmental change and the action required for mitigating or avoiding it make- together with other challenges - a reinterpretation of the right to development necessary, in political discourse and in decision-making, in public debate and with regard to the expectations of future human wellbeing connected with it.

This article therefore does not refer to the legal debate on the quality of the UNDRTD as an independent substantial right but to its importance in political discourse, the meanings it provides for debates on the content of development policies and processes, and on the rights and duties of states in this respect. The mainstream of the legal literature considers the UNDRTD as soft law and Sengupta's assertion that "RTD has by now been established as an international human right" is rather a minority statement. In political discourses and negotiations, however, RTD is an important reference, and negotiation results reflect this. The Rio Declaration of 1992 mentions the Right to Development in Principle 3 which calls for equitably meeting the developmental and environmental needs of present and future generations (de Feyter 2013). In the context of the UNFCCC, the right to development was translated into the principle of common but differentiated responsibilities and respective capabilities (CBDR-RC) which reveals a limited understanding of its universal approach. The CBDR-RC principle led to differentiated obligations: rich countries had to move forward and reduce their greenhouse gas emissions under the

\footnotetext{
${ }^{9}$ UNDRTD Article 1 second paragraph states: "The human right to development also implies the full realization of the right of peoples to self-determination, which includes, subject to the relevant provisions of both International Covenants on Human Rights, the exercise of their inalienable right to full sovereignty over all their natural wealth and resources".

${ }^{10}$ Sengupta (2006), p. 35.
} 
Kyoto Protocol, while developing countries only had to report their emissions. Under the Paris Agreement, this principle was reaffirmed, after controversial negotiations, which allows differential treatment in the light of different national circumstances; in the articles of the Paris Agreement, in particular on mitigation, finance and transparency; and by introducing new and dynamic ways of differentiation through the new principles of progression and highest possible ambition. ${ }^{11}$ The 2030 Agenda reflects many concerns that developing countries have rightly been emphasizing in the debate on the right to development, namely "inequalities in the international financial system, greater participation of developing countries in global decision-making on economic policy, and promoting a fairer trade regime". ${ }^{12}$ Rich countries from the North have been less successful in anchoring their interpretation of the right to development in the agenda, which focuses more on the responsibilities of national governments in developing countries than on their own, namely to establish "suitable domestic conditions in developing countries such as good governance, democracy and responsible economic management". ${ }^{13}$ Nevertheless, the reference in the 2030 Agenda to the UNDRTD helps to enhance participation and non-discrimination. ${ }^{14}$ In addition, the 2030 Agenda and the UNDRTD equally strongly emphasize the responsibility of states for implementation, through national policy efforts and international cooperation.

Summarizing, the Right to Development appears to address issues of distribution and burden-sharing both within and between countries, as obstacles for enjoying the right to development, and to favour approaches that are in the interest of today's poor. Global climate change and worsening environmental trends, however, raise questions that are more fundamental because these changes and trends result from the cumulative environmental effects of immense improvements in global human welfare achieved in the twentieth century. The following section will explain how global environmental change is defined, how it is linked with human development and how it manifests itself. After that, the article will take a closer look at the UNDRTD, how it could be linked with global environmental change, and make some proposals for concepts that could help to situate the UNDRTD within the challenges of the twenty-first century as exemplified in the 2030 Agenda.

\section{Global Environmental Change and Human Development}

Global environmental change is an area of research that started to emerge in the 1960s and 1970s. Two topics were seminal: in the natural sciences, a growing interest in understanding the effects of rising anthropogenic emissions of greenhouse

\footnotetext{
${ }^{11}$ Voigt and Ferreira (2016).

${ }^{12}$ De Feyter (2013), p. 1.

${ }^{13}$ De Feyter (2013), p. 1.

${ }^{14}$ Arts and Tamo (2016).
} 
gases into the atmosphere created space for the study of global warming and climate change and its interactions with industrialization and its infrastructures, land use and biodiversity. In economics, the 1972 report of the Club of Rome on the "limits of growth" 15 stirred a debate on the interactions between exponential economic and population growth and a finite supply of resources, the role of technological change therein and the dynamics that lead to either collapse or sustainability. ${ }^{16}$

In 2015, an international group of leading scientists from various disciplines published an article on nine "planetary boundaries" for human use of the Earth ecosystems and natural resources in a world characterized already by global environmental change. ${ }^{17}$ Out of the comprehensive interactions of land, ocean, atmosphere and life that together provide the conditions for the existence of the human species on Earth, the authors identified nine processes and systems that regulate the stability and resilience of the Earth System and that are affected by human-induced changes to the environment. These include climate change, land-system change, biodiversity losses (genetic diversity under threat), changes in biogeochemical flows of nitrogen and phosphorus (that is to modern agriculture), ocean acidification, atmospheric aerosol loading, stratospheric ozone depletion and novel entities that pollute air, water and soils (for example toxic compounds, genetically modified organisms, and nanomaterials). "Two of these, climate change and biosphere integrity, are what the scientists call 'core boundaries'. Significantly altering either of these core boundaries would drive the Earth System into a new state", which includes the crossing of thresholds towards dangerous and irreversible change (http://www.anthropocene.info/planetary-boundaries.php).

The depth and certainty of scientific knowledge on how close we are to these thresholds varies: with regard to ocean acidification, ozone depletion and freshwater use we know that human use is still within the safe area-improving in the case of ozone depletion but dangerously close to the boundary in the case of ocean acidification. Global warming is increasingly affecting freshwater resources. Changes in the climate and the land system are in the zone of uncertainty while the latter is quite close to the boundary towards high risks. Genetic diversity and phosphorus and nitrogen flows are in the high-risk zone as the rate of species extinction has increased to unprecedented levels in human history during the last five decades, as has the use of synthetic fertilizers in agriculture. It has not been possible to assess yet where we are with regard to the novel entities and atmospheric aerosol loading (http://www. anthropocene.info/planetary-boundaries.php).

Defined as the result of interactions between natural and societal processes at global level, global environmental change can be characterized first as being a transboundary process whose impacts affect poor people and poor countries

\footnotetext{
${ }^{15}$ Meadows et al. (1972).

${ }^{16}$ For a summary of the reception of the report by economics over time, and how the original computer simulation and scenarios conform with measured changes since 1972 see the summary and literature in Wikipedia: https://en.wikipedia.org/wiki/The_Limits_to_Growth.

${ }^{17}$ Steffen et al. (2015).
} 
disproportionately, due to their geographical location and their high socio-economic vulnerability (for the case of climate change, see IPCC Working Group II 2014).

Second, causes and impacts of global environmental change connect separate places over time and space, and the structure of causation is diffuse in itself. This is particularly true for global warming but also holds for the other processes that regulate the functioning of the Earth. Global warming today is the cumulative effect of greenhouse gas emissions of the last 200 years. These emissions occurred mainly in the centres of the industrial revolution, in Western Europe and the United States, but emission levels were high in the bloc of the former Soviet Union, too. In the last 20-30 years, absolute emissions grew exponentially in China as well as in India, Indonesia and other economically successful Asian countries. Impacts such as increased frequency and intensity of extreme weather events (droughts, floods, heat waves, storms), spread of vector-borne diseases (malaria, dengue) and rising sea levels (which will make coastal zones uninhabitable and lead to the disappearance of small island states) occur depending on geographies and climate, and not necessarily at places where emissions were generated. The generations who created the fossil-fuel economy and benefitted from it, and whose production and consumption patterns created global warming, will long be dead once impacts become apparent and the norm.

Emissions are caused mainly by energy use, and energy still overwhelmingly depends on the burning of fossil fuels. In the case of large utilities and energyintensive economic sectors responsibility for postponing the switch to renewable energy technologies can be attributed. At the same time, the dependency of economic reproduction, of consumption and lifestyles on energy use and fossil-fueled bound technologies at the same time diffuses responsibilities and make change cumbersome. Environmental impacts are associated with specific technological trajectories that generate income, employment, and fulfill individual and societal needs in specific ways. ${ }^{18}$ Moreover, increasing levels of income and prosperity in developing countries facilitate the reproduction of fossil-fuel based consumption and production patterns there, often at lower levels of energy efficiency.

The long causation chains between causes and impacts of global warming over time and space make it difficult to attribute legal responsibility and to address losses and damage, both for individual victims of climate change and for countries who suffer strong impacts without being large emitters.

Third, impacts of global environmental change do not only occur after long periods of time but they cannot be stopped easily, and sometimes they trigger irreversible processes of change with cascading effects. ${ }^{19}$ Examples include the melting of the ice shields in Greenland and the Antarctica, the weakening of the Gulf Stream that makes temperatures in Europe more amenable than usual in higher latitudes, and mass extinction of species.

\footnotetext{
${ }^{18}$ Leach et al. (2010).

${ }^{19}$ World Bank 2012).
} 
Fourth, the nine processes identified by Will Steffen and colleagues also interact with each other in complex ways. In most cases, linked impacts reinforce each other so that total impact is larger than the sum of all single impacts. ${ }^{20}$

Climate change is but one, albeit core, aspect of global environmental change. Since a few decades, environmental research is making efforts to understand the human impact on the earth system as a whole, by measuring the increasing human share in overall energy and material flows and the impacts this has on ecosystems and their functions. ${ }^{21}$ As a whole, human impact has put the planet's ecosystems and their ability to sustain human life on earth under huge stress. ${ }^{22}$ Human activity has changed half of the world's land surface, global energy and material flows exceed any natural flows, water resources, soils, forests and oceans are overexploited, and biodiversity is drastically reduced. This notion that the relationship between human society and nature has reached a new, unprecedented quality with far-reaching consequences for both led Nobel prize winner Paul Crutzen to define the present period since industrial revolution as a new geological epoch and to call it the Anthropocene. ${ }^{23}$ The Anthropocene "marks the beginning of a new era of responsibility, as in terms of technology, humankind has by now advanced so far that it could unbalance the Earth system to an extent that would have dire consequences for human societies and ecosystems". 24

Social environmental research shows that it has become increasingly difficult to empirically disentangle nature and society. ${ }^{25}$ The processes of environmental overuse are produced and shaped by specific social practices that are embedded in and constitute economic and social subsystems (agriculture/food systems, cities, transport) that in turn are simultaneously linked to these environmental trends in various ways. Social practices vary with local historical, socio-economic and institutional conditions, and at the same time are influenced by global production and consumption networks to which they are connected. Therefore, there is no uniform way in how levels of human development and levels of environmental use are linked with each other.

The indeterminate relationship between prosperity and environmental damage becomes clear when comparing the levels of human development achieved by countries with their ecological footprints. ${ }^{26}$ First, countries with a high level of human development have environmental footprints of nearly all sizes. No country, however, stays below the existing biocapacity per person. Second, the vast majority of countries whose environmental footprint is compatible with global sustainability as defined by the Global Footprint Network (GFN)—mostly from Africa—have low

\footnotetext{
${ }^{20}$ WBGU (2011, p. 45).

${ }^{21}$ This paragraph and the following three are taken from Scholz (2019) with minor changes.

${ }^{22}$ MA (2005).

${ }^{23}$ Crutzen (2002) and Steffen et al. (2007).

${ }^{24}$ WBGU (2011), p. 31.

${ }^{25}$ Leach et al. (2010).

${ }^{26}$ Wackernagel et al. (2017).
} 
levels of human development. However, there are also poor countries with high environmental consumption. Third, there is no country that achieves high levels of human development within the environmental limits defined by the Global Footprint Network. As a trend, improvements in human development are linked with increasing environmental consumption. ${ }^{27}$

This trend, together with the large variations documented between countries, call for deeper analysis of the relationships between human society and nature, and how they are connected with and shaped by social inequalities, in order to explain both reinforcing linkages and pathways where decoupling between improved prosperity and environmental degradation can be observed. This is relevant for analytical and normative reasons and for better understanding current dominant development pathways, how they interact with social organization, with political and economic institutions, which in turn affect the ability to adopt changes required for making human prosperity sustainable and universal.

\section{What Follows from This for the Right to Development? Human Development Within the Limits of the Earth's Ecosystems}

Before I reflect upon what these considerations mean for the Right to Development, I first want to highlight some further aspects of the UNDRTD that are relevant for these reflections.

The Declaration on the Right to Development adopted by the UN General Assembly in 1986 does not define development as such but understands it to be a process for the full realization of all human rights. Development is declared to be an "inalienable human right" (Article 1) that depends on a comprehensive process that increases individual and collective wellbeing, and aspires to achieve social justice. States have the "primary responsibility for the creation of national and international conditions favourable to the realization of the right to development" (Article 3.1), i.e. to ensure that all persons living in their territory enjoy their rights as humans. They also have the "duty to co-operate with each other in ensuring development and eliminating obstacles to development" (Article 3.3), specifically by promoting a new international economic order. Article 4 establishes that states should implement adequate development policies, in their own territory and in support of developing countries, as a complement to their own efforts. Article 6 re-affirms the principle of international cooperation with a view to the respect of all human rights and specifically mentions that states "should take steps to eliminate obstacles to development resulting from failure to observe civil and political rights, as well as economic, social and cultural rights" (Article 6.3).

${ }^{27}$ Jackson (2017). 
The reference to the new international economic order situates the Declaration on the Right to Development in the context of dependency theories and their understanding of the structural characteristics of post-colonial economies and societies as well as of international trade and production being an obstacle and not an opportunity for developing countries to benefit from international economic integration and growth. A development process that is guided by human rights and thus participatory in process and people-centred in its content therefore requires changes in these structures and in international political and economic relations.

Seen from this perspective, development seems to mean catching-up with industrialized countries, with regard to their material levels of wellbeing, their institutional structures and political orders. The right to development is derived from a critical view of supposedly universal principles that nevertheless allow for economic and political structures that systematically exclude developing countries. ${ }^{28}$ Questions of environmental justice-negative social effects of environmental use, unequal distribution of pollution and other environmental bads to the detriment of the poor, and adverse distributive effects of environmental policies-do not figure in the UNDRTD. Neither does global environmental change.

After 1986, there were two significant additions made to the UNDRTD by two documents, a conceptual one and an institutional one:

- In 1993, the Vienna Declaration of the World Conference on Human Rights reaffirmed the Right to Development in a succinct and abbreviated version in its Article $10 .^{29}$ It then connected it with the concept of sustainable development (adopted in the final declaration of the UN Conference on Environment and Development in Rio de Janeiro in 1992) by stating that the right to development "should be fulfilled so as to meet equitably the developmental and environmental needs of present and future generations" (Article 11). This addition allows the DRTD to widen its normative horizon and include collective rights of future generations, juxtaposing them both to collective interests in fulfilling the needs of all in the present, and to strong individual or group-specific interests that may hamper meeting future needs. An important blank spot remains that has been filled by the 2030 Agenda: there is no acknowledgement of a "healthy

\footnotetext{
${ }^{28}$ For a deeper analysis of how the RTD is interpreted over time it makes sense to distinguish between its normative core and the specific calls for reforms of multilateral institutions and rules (such as the voting rights in the International Financial Institutions or multilateral trade and investment policy) that are seen as obstacles for the RTD.

${ }^{29}$ Article 10 of the Vienna Declaration 1993 reads: "The World Conference on Human Rights reaffirms the right to development, as established in the Declaration on the Right to Development, as a universal and inalienable right and an integral part of fundamental human rights. As stated in the Declaration on the Right to Development, the human person is the central subject of development. While development facilitates the enjoyment of all human rights, the lack of development may not be invoked to justify the abridgement of internationally recognized human rights. States should cooperate with each other in ensuring development and eliminating obstacles to development. The international community should promote an effective international cooperation for the realization of the right to development and the elimination of obstacles to development."
} 
environment" as a prerequisite for development and that could be considered a (collective) human right, too. ${ }^{30}$

- The states' responsibility to act in relation to the right to development was specified in a document elaborated by a High-Level Task Force in 2010 that had been established by an Open-Ended Working Group under the Council of Human Rights. According to this report, "there exist three levels of States' responsibility (...): (i) States acting collectively in global and regional partnerships; (ii) States acting individually as they adopt and implement policies that affect persons not strictly within their jurisdiction; and (iii) States acting individually as they formulate national development policies and programmes affecting persons within their jurisdiction" (Vandenbogaerde 2013, p. 200). These three levels explain how states can act in order to ensure the individual and the collective dimension of the right to development ${ }^{31}$ : through policies within their borders, by producing spillover effects across borders, and by explicit global or regional collective action. Collective rights and collective action are crucial for addressing the causes of global environmental change and for avoiding that rising levels of human prosperity increase environmental harm.

Making the Right to Development meaningful in a world increasingly marked by global environmental change requires concepts and norms that help to address the ways in which global environmental change interacts with specific ways for fulfilling human needs and achieving high levels of human development.

The historian Dipesh Chakrabarty has reflected about the question whether and how the Anthropocene requires new concepts when analyzing human prosperity, compared to the previous Earth age, the Holocene. His main conclusion is that a critique of capitalist globalization is insufficient for understanding human history in the age of the Anthropocene. First because the energy and material intensive industrial civilization is not limited to capitalist economies, and second because the Anthropocene "has brought into view certain other conditions for the existence of life in the human form that have no intrinsic connection to the logics of capitalist, nationalist, or socialist identities. They are connected rather to the history of life on this planet, the way different life-forms connect to one another, and the way the mass extinction of one species could spell danger for another. Without such a history of

\footnotetext{
${ }^{30}$ The Human Rights Council acknowledged the reinforcing relationship between the quality of the environment and the full enjoyment of human rights and appointed an independent expert on human rights and the environment in 2012, and later extended his mandate as special rapporteur in 2015. See http://www.ohchr.org/EN/Issues/Environment/SREnvironment/Pages/SRenvironmentIndex. aspx.

${ }^{31}$ The German strategy for sustainable development of 2016 for the implementation of the 2030 Agenda adopts a similar three-level approach: "Alongside measures with effects in Germany, there are also measures by Germany with a global impact. In addition, there is also the support of other countries in the form of bilateral cooperation (measures with Germany)", see Federal Government of Germany (2016), p. 3. Unfortunately, this definition omits international collective action.
} 
life, the crisis of climate change has no human 'meaning'. For, as I have said before, it is not a crisis for the inorganic planet in any meaningful sense". ${ }^{32}$

Chakrabarty therefore proposes to introduce the category of human species for capturing the new dimension the Anthropocene adds to the future of humanity, and to cross-hatch the analysis of post-colonial capitalism with universal thinking in this sense. With this category it is possible to grasp the extent of the "shared catastrophe" all humans have fallen into once they became a geological agent, and to focus not only on internal conflicts within human society but to see it as part of the history of the web of life on the planet.

Is this a viable concept for making sense of the new quality of time and space covered by the relationship between human rights and the right to development in the Anthropocene? Democratic political systems, their institutions and procedures for making legitimate decisions are not adjusted to thinking in terms of the human species. Their concept of the collective has been elaborated and refined on the premise of national jurisdictions and laws. Moreover, democracies and their deliberations rely on the premise of an open future that individuals and groups can shape (and re-shape) according to their preferences.

Two fundamental dimensions of global environmental change are challenging for contemporary democracies: responsibility for decisions that have impacts over long times and for future generations (inter-generational justice) and beyond the national territory and across current generations (intra-generational justice). The cumulative effects of current production and consumption patterns over time reduce future opportunities for human prosperity-enjoying the freedom of an open society today will close the future for the generations to come (actually already for the current generation of children and teenagers) if no corrective action is taken against irreversible global environmental change. There are no practical rules for taking into consideration the rights of future generations into today's decisions. Extraterritorial responsibilities and the need for respective rules in the area of economic, social and cultural rights have been defined in the Maastricht Principles on Extraterritorial Obligations of States which recur to the UN Charter and human rights instruments, not to the UNDRTD. These principles are only slowly being accepted and translated into law and rules to be followed by non-State actors by some national governments. Others reject them. During the last four decades, economic globalization was advanced through deregulation and liberalization of national markets, and in this process, the notion of public interest to which collective public action is committed has weakened considerably. The less regulation in the public interest seemed necessary and legitimate for human prosperity at national level, the less it was possible to secure effective engagement in global public action for global public goods.

In an open, democratic society, these challenges can only be addressed if the destructive effects of human use of the environment are reflected upon collectively, and if the addressee of the rules is humanity as such (to reflect the threat to human

${ }^{32}$ Chakrabarty (2009), p. 217. 
species, following Chakrabarty). This could mean to introduce humanity as a third right-holder in addition to individuals and peoples. From the perspective of naturesociety relationships, however, this would also require norms about the relationship between humanity and other plant and animal species. ${ }^{33}$ These challenges need to be taken up by dialogue, debate and decision-making, at local, national, regional and global levels of the executive, in legislatures and the judiciary, in other sectors of society, i.e. academia, the private sector, trade unions, and civil society organisations. Addressing the causes and the impacts of global environmental change on human prosperity, moreover, requires that international cooperation and collective public action in the interest of the global common good be strengthened and intensified.

Two proposals for qualifications to the right to development and, in consequence, as guidance for democratic decision-making, can be derived from this reasoning:

- Public/development policies in all countries have to respect the best knowledge on the limits of the earth's ecosystems and set their objectives and measures accordingly, in order to avoid trespassing local or global boundaries for safe human use of natural resources and sinks, and thus mitigate threats to the existence of humanity.

- Public/development policies in all countries shall not diminish the right to development/the full enjoyment of all human rights of others (intra- and intergenerational justice for humanity).

These qualifications and the reasoning and evidence that justify them need to be debated in order to adjust the international legal framework for human rights (and national law) not only to the challenges of economic globalization but also to those of global environmental change.

In 2013, there was a debate whether the UNDRTD should be strengthened by a legally binding framework convention ${ }^{34}$ or whether this is not necessary as the Maastricht ETO Principles show. ${ }^{35}$ Vandenbogaerde rightly says that the realization of human rights (and of development) requires individual agency, and that the duty of States is to enable individuals to carry out this agency. ${ }^{36}$ Global environmental change, however, shows the limits of individual agency and the urgency of international collective action, as stated in the 2030 Agenda, in the twenty-first century. Maastricht ETO Principle 29 considers that: 'States must take deliberate, concrete and targeted steps, separately, and jointly through international cooperation, to create an international enabling environment conducive to the universal fulfilment of economic, social and cultural rights, including in matters relating to bilateral and multilateral trade, investment, taxation, finance, environmental protection, and

\footnotetext{
${ }^{33}$ In her most recent book, Donna Haraway reflects about how to increase humanity's empathy with other species, see Haraway (2016).

${ }^{34}$ De Feyter (2013).

${ }^{35}$ Vandenbogaerde (2013).

${ }^{36}$ Vandenbogaerde (2013), p. 200.
} 
development cooperation' ${ }^{37}$ It is an advance that environmental protection is mentioned here, although at the same level of priority as financial and economic systemic issues. This ignores the risks of environmental change at species level.

Vandenboegarde goes on: "Both the right to development and the concepts of extraterritorial and transnational human rights obligations indicate that there is a fissure between today's human rights violations of a structural nature and the existing legal framework. Both share the idea that States and other powerful non-State actors have consequent obligations in filling this fissure, and both have to fight the reluctance or outright refusal of (mostly developed) States to acknowledge those obligations. ${ }^{38}$

It is clear that states (and non-state actors) do not only need to accept their extraterritorial responsibilities with a view to human rights and their foundation in the dignity of the individual, but also with regard to humans as a collective, the human species.

If humanity is introduced as a third category of right-holders (in addition to individuals and groups), then the norms that rule the relationships between species or life-forms as interdependent parts of the web of life come into focus. A third proposal consequently would be to transcend the conceptual boundaries of human rights and establish the rights of life forms, including humans as well as plants and animals in the broadest sense, and norms that govern their interdependencies.

Summarizing, the fundamental linkages between global environmental change and human prosperity, and the norms established in the 2030 Agenda, the Paris Agreement and the UNDRTD define five new tasks for states as duty bearers. First, states need to regard environmental protection and the provision of global environmental goods as fundamental and necessary areas of public policy and action for the full realization of all three generations of human rights (as defined in Articles 3, 4 and 6 of the UNDRTD). Second, this includes appropriate collective action at national, regional and global levels (legal frameworks, public policies and measures with regard to areas of public responsibility and with regard to respective guidance for non-state actors). Third, states have to ensure that they respect and fulfil extraterritorial obligations directly and indirectly towards people within and beyond their own jurisdiction and towards the global environment. Fourth, they have to respect the rights of future generations when making decisions today that reach out into the future. Finally, states should engage in first steps for developing a normative framework for the rights of all life-forms and the relationships between them.

\footnotetext{
${ }^{37}$ Quoted in Vandenbogaerde (2013), p. 206.

${ }^{38}$ Vandenbogaerde (2013), p. 208.
} 


\section{References}

Arts K, Tamo A (2016) The right to development in international law: new momentum thirty years down the line? Neth Int Law Rev 63:221-249. https://doi.org/10.1007/s40802-016-0066-x

Chakrabarty D (2009) The climate of history: four theses. Crit Inq 35(2):197-222

Crutzen P (2002) Geology of mankind. Nature 415:23

De Feyter K (2013) Towards a framework convention on the right to development. Friedrich Ebert Stiftung, International Policy Analysis/Dialogue on Globalization, Berlin

Federal Government of Germany (2016) German Sustainable Development Strategy 2016. Federal Government, Berlin. https://www.bundesregierung.de/Content/DE/_Anlagen/2017/02/201702-27-nachhaltigkeit-neuauflage-engl.pdf?_blob=publicationFile \&v $=1$

Fukuda-Parr S (2016) Human rights and politics in development. In: Goodhart M (ed) Human rights: politics and practice, 3rd edn. Oxford University Press, New York, pp 198-215

Haraway D (2016) Staying with the trouble: making kin in the Chthulucene. Duke University Press, Durham

IPCC WG II (Intergovernmental Panel on Climate Change Working Group II) (2014) Climate Change 2014: impacts, adaptation, and vulnerability. Summary for policymakers. IPCC, Geneva

Jackson T (2017) Prosperity without growth. Foundations for the economy of tomorrow, second expanded and revised edition. Routledge, Abingdon

Leach M, Scoones I, Stirling A (2010) Dynamic sustainabilities: technology, environment, social justice. Earthscan, London

MA (Millennium Ecosystem Assessment) (2005) Ecosystems and human well-being. Current state and trends. Island Press, Washington, DC

Mayer B (2016) Human rights in the Paris Agreement. Climate Law 6:109-117. https://doi.org/10. 1163/18786561-00601007

Meadows DH, Meadows DL, Randers J, Behrens WW III (1972) The limits to growth. A report for the Club of Rome's Project on the predicament of mankind. Universe Books, New York. http:// www.donellameadows.org/wp-content/userfiles/Limits-to-Growth-digital-scan-version.pdf.

Retrieved 1 May 2018

Scholz I (2017) Herausforderung Sustainable Development Goals. In: Michelsen G (ed) Die Deutsche Nachhaltigkeitsstrategie: Wegweiser für eine Politik der Nachhaltigkeit. Hessische Landeszentrale für politische Bildung, Wiesbaden, pp 23-39

Scholz I (2019) The relevance of environmental research for development studies. In: Baud I, Basile E, Kontinen T, von Itter S (eds) Building development studies for the new millennium (EADI Global Development Series). Palgrave Macmillan, Basingstoke, pp 337-359. ISBN 978-3-03004051-2

Sengupta A (2006) The human right to development. In: Marks SP, Andreassen BA (eds) Development as a human right: legal, political and economic dimensions. Harvard School of Public Health, Cambridge, MA

Steffen W, Crutzen PJ, McNeill JR (2007) The anthropocene: are humans now overwhelming the great forces of nature? Ambio 36(8):614-621

Steffen W et al (2015) Planetary boundaries: guiding human development on a changing planet. Science 347:1259855. https://doi.org/10.1126/science.1259855

Vandenbogaerde A (2013) The right to development in international human rights law: a call for its dissolution. Neth Q Hum Rights 31(2):187-209

Voigt C, Ferreira F (2016) 'Dynamic differentiation': the principles of CBDR-RC, progression and highest possible ambition in the Paris Agreement. Transnatl Environ Law 5(2):285-303. https:// doi.org/10.1017/S2047102516000212

Wackernagel M, Hanscom L, Lin D (2017) Making the Sustainable Development Goals consistent with sustainability. Front Energy Res 5, Article 18. https://doi.org/10.3389/fenrg.2017.00018 
WBGU (Wissenschaftlicher Beirat Globale Umweltveränderungen - German Advisory Council on Global Change) (2011) World in transition: a social contract for sustainability, Flagship Report 2011. WBGU, Berlin

World Bank (2012) Turn down the heat - why a $4{ }^{\circ} \mathrm{C}$ warmer world must be avoided. World Bank, Washington DC

Imme Scholz is a sociologist and Acting Director of the German Development Institute (Deutsches Institut für Entwicklungspolitik DIE) since 2009. Before, she headed the department on environmental policy and natural resource management at DIE, and introduced work related to climate change into the institute's research and policy advisory. She is a member of the German Council for Sustainable Development since 2013. In 2015 she joined a CCICED task force on greening China's South-South Cooperation. She has published extensively on several topics at the interface of environment and development, including the 2030 Agenda and the SDGs, adaptation to climate change, and sustainable forest use. In the 1980s, she studied sociology at the Freie Universität Berlin where she did her doctorate in 1999 after joining DIE in 1992. Between 1999 and 2002, she was on leave and worked for German development cooperation as an environmental policy advisor in the Brazilian Amazon.

Open Access This chapter is licensed under the terms of the Creative Commons Attribution 4.0 International License (http://creativecommons.org/licenses/by/4.0/), which permits use, sharing, adaptation, distribution and reproduction in any medium or format, as long as you give appropriate credit to the original author(s) and the source, provide a link to the Creative Commons licence and indicate if changes were made.

The images or other third party material in this chapter are included in the chapter's Creative Commons licence, unless indicated otherwise in a credit line to the material. If material is not included in the chapter's Creative Commons licence and your intended use is not permitted by statutory regulation or exceeds the permitted use, you will need to obtain permission directly from the copyright holder.

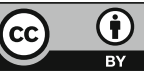

